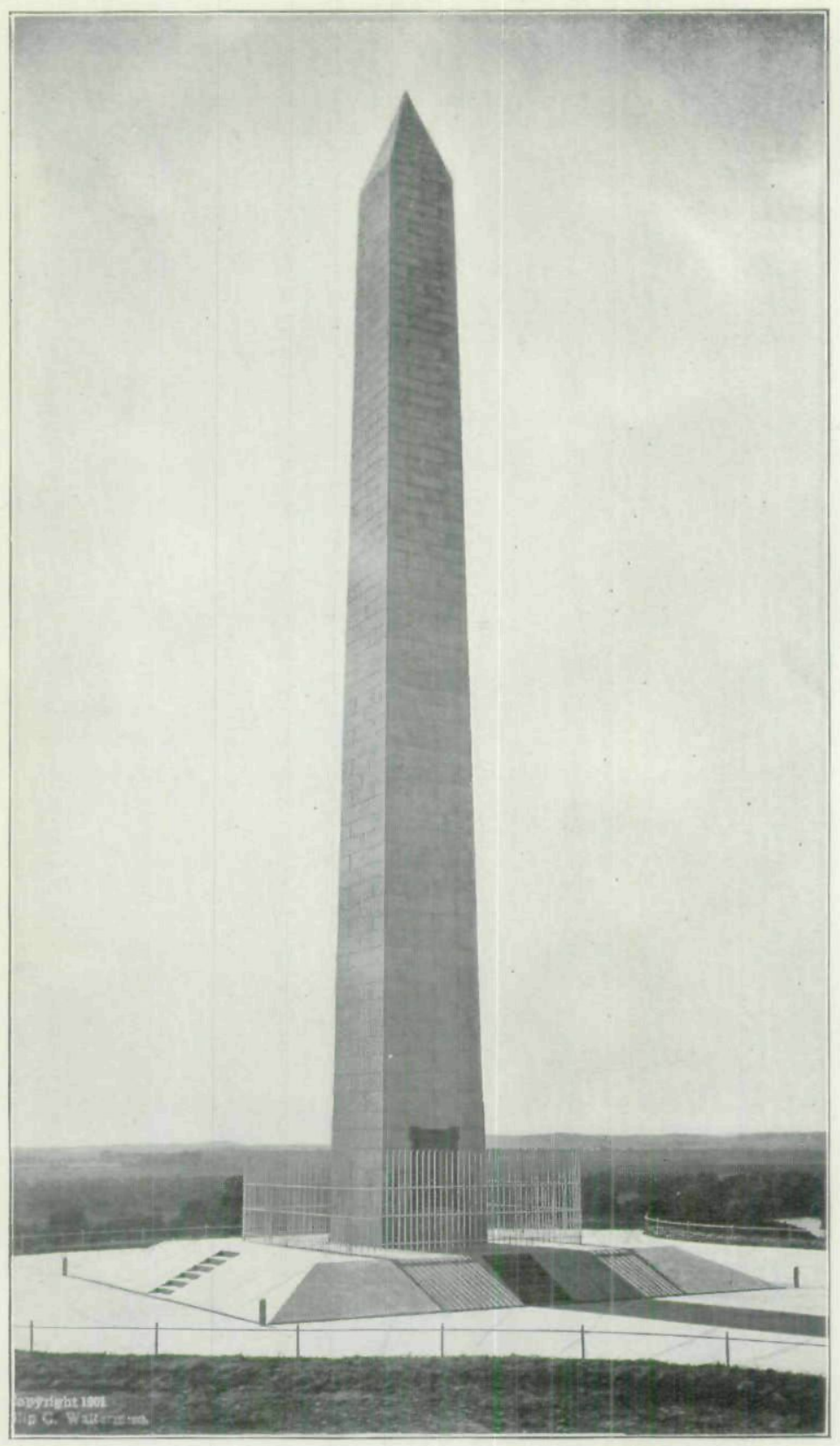

THE FLOYD MONUMENT, ERECTED AT SIOUX CITY, IOWA, AND DEDICATED MAY 30, 1901.

In commemoration of the acquisition of Louisiana and in honor of the first explorers and pioneers of the West. 


\title{
THE EXPANSION OF THE REPUBLIC WEST OF THE MISSISSIPPI.
}

\author{
BY HON. JOHN A. KASSON.
}

[Address at the dedication of the historic monument erected at Sionx City, Iowa, in commemoration of the acquisition of Louisiana and in honor of the first explorers and pioneers of the west, May 30, A. D. 1901.]

Fellow Citizens: The occasion which has brought this great assembly together evokes the memory of many important events in our national history. To all except the aged pioneer it seems impossible that only a century ago all the fair land we look upon from this eminence and all westward to the continental range of mountains was a desert, and under the dominion of despotic Spain; that all the land eastward to the Mississippi, as well as all toward the setting sun, was at that time, and had been for unrecorded ages, in possession of wild beasts and of savages of the human race.

Only ninety-seven summers have passed since a roving Indian standing on this highland would have witnessed a scene altogether new and strange to him. A barge 55 feet long, having a forecastle forward and a cabin aft, carrying 22 oars and a square sail, drew near this shore on its passage up the great river of the Missouri. It was accompanied by two smaller open boats; and altogether they carried about forty pale-faces, chiefly soldiers. A number of the men landed at the foot of this bluff and ascended it, bearing gently a burden which they deposited in a grave, and marked the spot with a rude cedar post. Upon its face was inscribed the name of Sergeant Charles Floyd of the United States army, who had died that day, August 20, 1804. No priest's prayer or blessing was heard; but certain simple honors of the military service broke the sad silence of the ceremony. After this solemn act these pale-faces descended the bluff to the boats; and the barge with its pirogues moved a mile up the river into the mouth of a tributary stream, then 30 yards wide, where the company camped for the night. The brilliant 
stars of this western firmament drew their eyes and their thoughts heavenward, whither their brave companion had just departed, and made the scene more beautiful than the day. In honor of the dead they dedicated to his memory both the burial bluff and the little river in which they were moored. Thenceforth for all time these two objects in nature shall preserve the name of their dead comrade. So does a name - a mere sound in the air-become more imperishable than any structure of human workmanship. Unaffected by flood or tempest, or war's destructiveness, it is repeated from father to son, for all generations.

Thus prematurely died and was buried the courageous young Kentuckian. He had enlisted for a long and adventurous service which was expected to lead him along mighty rivers, among many wild and strange tribes, and over unknown mountains, until his eyes should finally rest upon that great and distant ocean which washed the western shores of the unexplored continent, Although he perished in the earlier stage of the enterprise this lonely burial, which cut off his hopes and his career, has preserved his name and memory among mankind above that of his comrades who continued the struggle to the end, and who returned to receive the rewards voted by an appreciative Congress.

\section{THE GREAT EXPLORATION OF 1804-6.}

President Jefferson had in the winter of 1802-3 conceived the plan of an exploring expedition up the Missouri and across the mountains to the Pacific with the view of scientific investigation and of opening trade with the Indians, and also of finding a feasible route for the limited commerce of that day across the continent. He hoped also to divert the fur trade of the northwest into the hands of the Americans. He obtained an appropriation from Congress of $\$ 2,500$, with which he proceeded to organize a company under the leadership of Captains Meriwether Lewis, his private secretary, and William Clark. The details of that expedition are interesting, but are already so well known that there is no occa- 
sion to repeat them in this address. Its success was only accomplished by the exercise of all the virtues known to the life of the frontiersman. It required valor, perseverance, mutual trust, self-confidence, vigilance, knowledge of the instincts and characteristics of the savage, inventive resource, endurance, continuous toil, and unlimited courage. The explorers left their camp in Illinois, opposite the mouth of the Missouri, on May 14, 1804, and sixteen days from their departure saw the last cabin of the white man, about one hundred miles from the mouth of the river. It was ninety-seven years ago this day that they bade farewell to these huts of semi-civilization. Thenceforward for many, many weary months, upward along the endless windings and shifting sandbars of that treacherous river, and through the gorges and over the trackless ridges of confused mountains, and down the unknown streams rushing to the Pacific ocean, abandoning their old boats and building new, in peril of starvation, in peril of drowning, in peril of wild beasts and of wily savages, they pushed their way over flooding waters and pathless forests to their desolate destination on an uncharted ocean coast in the far region of the sunset. Every morning found them ignorant where their evening would be. The sun by day and the stars by night were the only familiar things of the visible universe. When in the opening of a second winter season they arrived on the bleak and desolate ocean shore at the mouth of a great river, it was only to encounter the incessant cold rains of winter, the increasing dangers of famine, and the attacks of disease. After four tedious months of waiting beside the deserted waters of the Pacific, hoping vainly for sight of a vessel that should take their homeward messages around Cape Horn, in the third spring of their expedition they turned their steps again into the continental wilderness on their return (if God should permit it) to the lands of civilization and expectant friends.

Again the weary hunt for wild food, again the endless tugging at the oars upstream, again the rugged transit of 
mountain ranges, once more the search for new passes and new waters of navigation in the tangled web of mountains, until at last, in the summer of 1806 , their boats were again launched upon the Missouri. Then for the first time they felt themselves truly "homeward bound." Now the swift current of the great stream which was lately their enemy became their friend. Every lapping wavelet now sang of the nearing home. The stars, ever brilliant in that clear atmosphere, now seemed to shine with increasing luster as they rose up from the distant east, where anxious friends were awaiting the long-expected tidings. Familiar scenes of old camping-places appeared as they swiftly descended the river. More cheerily than on the upward voyage they now leaped into the stream to push their boat from the ever-lurking, ever-changing sandbars. Instead of fifteen or twenty miles a day as on their upward voyage, they now counted fifty, sixty, even seventy miles per day. There was little halting on their homeward course. But as they came by the bluff on which we are now standing the strong magnet of memory drew them to the shore. Once more the expedition halted at this landing that they might visit the grave of their dead comrade. They restored it to a condition of safety, and then bade the sacred deposit a long farewell. Little did they know-not one of the toil-worn heroes ever dreamed-of a future scene like that we look upon today. They saw only a solitary grave-mound in a vast desert region, far away from the abodes of civilization. We behold a splendid monument commemorating the spot where they laid their comrade in his last camping-ground, while jubilant thousands celebrate the brilliant deeds of the men who then sailed sadly away from the shore. They looked upstream and eastward upon a limitless solitude, stretching far away to the north and to the Mississippi. Our eyes look upon a populous and prosperous city which shall watch forever over this grave, and around it a rich and happy state of the American Union, with more than two millions of patriotic inhabitants, who today recall 
with pride the story of the first American pioneers of the great west. It is a transformation scene unmatched in any oriental story. But these pilgrims of the wilderness, ignorant and undreaming of all this incredible future, passed on, plying their oars, until at the end of nineteen days they met a joyous welcome from the villagers of St. Louis, and rested from their labors.

THE HISTORIO COMMEMORATION.

But this lofty monument is not erected solely to commemorate the modest life and humble career of the army sergeant whose bones were deposited in this soil long before the plow of civilization had disturbed it. Nor will this memorial only serve to celebrate the splendid exploration accomplished by his more fortunate companions. It also perpetuates the memory of a great historic act which influenced the fate of three nations, and opened the way to new liberties and increased happiness for mankind. It changed the development of our people, and gave a new pathway to the march of our young republic. It is this historical significance of the monument which induced the national congress, the legislature of Iowa, and the patriotic people of Sioux City to combine their efforts for its erection. It is my honorable and welcome duty today, fellow citizens, to invite your attention to the history of that great acquisition in our national progress which this monument will forever commemorate, and to indicate its influence upon the later destinies of the republic.

CHANGING FORTUNES OF LOUISIANA.

Before the outbreak of the Anglo-French war of 1756 the French king claimed under the name of "Louisiana" not only all of the Mississippi Valley west of that river, but also all the valley on the east of it lying north of Spanish Florida and eastward to the Alleghany mountains. The country north of the upper Ohio, however, was regarded as a part of Canada. The Count de Vergennes in his memorial on the subject, addressed to the king of France, says that the Appa- 
lachian mountains "separate the new France from the new England as distinctly as in Europe the mountains of the Pyrenees separate France from Spain."*

The Louisiana of that day may be generally described as embracing the whole region north of Spanish Mexico and Spanish Florida, from the Alleghanies to the Rocky Mountains, and from the sources of the Mississippi to its mouth, with the exception of that northeastern part which was tributary to the great lakes north of the Ohio, and was therefore associated with Canada.

The French were very active in establishing trading posts and making agreements with the Indians for common hostility to the English. Along the undefined eastern boundaries aggressions were continually occurring without waiting for declarations of war. When the war of 1756 came it proved exhaustive for both parties, but ended most disastrously for the French. They were obliged in the end to surrender to the British all Canada, and all of Louisiana lying east of the Mississippi, with the exception of New Orleans and the block of adjacent land extending east to the boundary of west Florida. The delta east of the river, and all the remainder of Louisiana to the west and northwest of the river as far as the mountains, was about the same time ceded by France to Spain in compensation for her losses in the war as the ally of France.

The retention by the French king in his treaty with England of the lower east bank of the river, which gave to the jealous Spaniard the control of both banks for a long distance above the mouth, and of the whole gulf coast, was destined to cause much angry excitement and trouble in the future, with much contention between the United States and Spanish governments; and it led later to a great change in the policy of the United States. The treaty of peace of 1763 assured to England the free navigation of the river to its mouth.

\footnotetext{
*"Separent aussi distinctement la Nonvelle de France de la Nouvelle Angleterre, que les Monts Pyrenees separent, en Europe, la France d'avec l'Espagne."
} 
But commerce in barges and flatboats required a depot near New Orleans for its transfer to ocean-going vessels. France, however, had relieved herself of all trouble on this account by her secret transfer of the territory to Spain. After the peace of 1763 England found French interests withdrawn from the American continent, and Spain was in possession of all the Mississippi region which France had owned or claimed, except that portion toward the Alleghanies and above the Ohio, which was ceded by the treaty to England.

This was the situation when our revolutionary war again disturbed the international conditions in respect to Louisiana. Naturally the sympathies of the French people and government were with our American patriots because England was our adversary. But the Memoir of Count de Vergennes, before referred to, shows that the motive of France for participating in the revolutionary war as our ally was found in the hope of inducing Spain to retrocede Louisiana and of recovering Canada for herself. The Memoir expressly mentions the danger to both Spain and France if the Americans should succeed in their revolution. The French statesman says plainly that "the United Provinces of America, after shaking off the metropolitan yoke, will be in a condition to give the law to France and Spain in all America, and they will invade their possessions at the moment when the two crowns will be least thinking of it." The French government was not so desirous for our success as for the loss by England of her American colonies and later acquisitions, and for the restoration to France of her former possessions. But even with her aid the war had no such result. England retained Canada and conceded to the revolted colonies their independence, together with all the territory held by England south of Canada and east of the Mississippi.

This territory seemed to our fathers vast enough for many generations of Americans. So late as 1801 Jefferson in his inaugural message congratulated the American people on "possessing a chosen country, with room enough for our de- 
scendants to the hundredth and thousandth generation." And yet in that same generation, during that very administration, the expansion of the territory of the republic began, not by will of president or government, but by that providential force of development that has so often in our history overborne or compelled the will of man. The story of this wonderful transformation of public opinion and statesmanship may be briefly told.

After the establishment of our independence, and indeed before it, our already scattered population had begun to feel its way across the Alleghanies into the fertile lands of the great valley beyond. All the transportation of their products seaward must follow the current of the rivers flowing into the Gulf of Mexico. Spain, now holding all the outlets through East and West Florida, and the entire gulf coast as far as Mexico by her acquisition of Louisiana, was arbitrary, selfish, and jealous of this right of transit through her territory. The United States government, by treaty of 1795 , had secured from Spain the right of depot at New Orleans for produce of the United States for the term of three years only. with provision for its continuance or for the establishment of another depot on the banks of the river. For a few years this arrangement was continued undisturbed. Then came a report from Europe that Spain under the commanding influence of Bonaparte had retroceded New Orleans and the entire province of Louisiana to France. In the subsequent excitement among the colonists the Spanish Intendant for some unknown reason cancelled the privilege of depot for our citizens. The Americans of the whole valley suddenly became aware of the frail tenure by which they held their commercial privileges. The entire valley became angrily excited, and was ready for immediate war and the capture of New Orleans if the depot privileges were not restored.

The report of the retrocession was afterward verified, and the title to Louisiana was again in France. It had been effected by a secret treaty executed in October, 1800 , but the 
terms were not published until many years afterward. The Americans of the valley, foreseeing the closing of their only commercial gateway, flooded Congress with their remonstrances, threatened to take measures for their security into their own hands, and boldly announced that their national allegiance depended on national protection. The more violent among them indicated the possibility of organizing an independent republic west of the Alleghanies, of seizing the control of the Mississippi and its valley, and expelling both France and Spain.

President Jefferson became profoundly alarmed by the energetic action of the west. He wrote to our minister (Livingston) at Paris that the possession by France of New Orleans would force the United States into alliance with England. He summoned Monroe to go with all speed of preparation on a special mission to Paris, the object of which was declared to be to purchase New Orleans and the Floridas, or so much of them as the powers in possession could be persuaded to part with. His purpose was wholly limited to the question of acquiring lands or permanent depots on the east of the Mississippi, and on the rivers running through Florida, for the convenience of our commerce which required outlets to the Gulf of Mexico, the northern shore of which would now be wholly controlled by Spain and France against the interests of the United States. This control by two foreign and allied powers was rightfully regarded as more dangerous to American interests than was the sole dominion of Spain. France under Bonaparte, then First Consul, was a much more dangerous neighbor than the King of Spain. The simple presence of French sovereignty at the mouth of the Mississippi was a provocation to the hostile fleets of Europe, and particularly an invitation to the fleets of England to enter and seize New Orleans and the mouths of that great river. This would establish Great Britain, already entrenched upon our northern frontier, on the other flank of the young republic, involving a thousand dangers to our growing interests in the newly-settled valley of the west. 
French recklessness of international obligations on the high seas had already been disastrous to our commerce on the Atlantic ocean. Eastern merchants had numerous and just claims against the French for their seizures of our vessels and cargoes on the ocean, and now they were to control also the commercial outlet of the continental inland, and to invite thither the presence of warlike fleets. The instinct of danger which developed itself in the west was fully justified. Jefferson, who during his long residence in Paris had become impregnated with French ideas and French sympathies, was slower in appreciating the dangers than were the people of the valley. Indeed his adhesion to French ideas and French interests had years before caused a certain alienation of sentiment between him and Washington. The terrible excesses of the French revolution, its gross infidelity and its shocking bloodshed in the effort to abolish Christianity and law, had offended all of Washington's sentiments of religion and humanity. The sympathies of Washington were on the side of the religious civilization of his English forefathers; while Jefferson looked complacently upon the violent destruction of all that was sanctified by ages of faith and custom. So now after Washington's death, himself in the president's chair, Jefferson was far behind other responsible citizens of the republic in his appreciation of the perils arising from French recklessness in resort to war and international violence. He did not lead, but followed the people in their protest against the fresh introduction of the power of France into the very center of our continent.

THE PURCHASE OF LOUISIANA A SURPRISE TO THE UNITED STATES GOVERNMENT.

Jefferson's proposed measure of relief was limited, and altogether inadequate to provide for the future interests of the United States. His instructions to his envoys was to obtain "a cession to the United States of New Orleans and of West and East Florida, or as much thereof as the actual proprietor can be prevailed upon to part with." That is to say, 
their attention was called exclusively to the gulf coast line extending from the Mississippi to the Atlantic. This appeared to be the maximum of his wishes. There was no hint of our requiring or of purchasing the great territory west of the Mississippi. He then proceeded to instruct them touching a possible reduction of even this demand, if necessary. If no grant of territorial jurisdiction could be obtained they were to secure mere rights of deposit, with the privilege of holding real estate for commercial purposes. In respect to the Floridas, the envoys were to secure depots at the mouths of the rivers which ran from the United States through Florida to the sea, together with their free navigation. And the sum within which they were to negotiate for any or all of these concessions was two millions of dollars.

It thus appears that Jefferson had never contemplated the acquisition of what is called the "Louisiana Purchase." Popular opinion has attributed to him a remarkable and statesmanlike foresight in negotiating for that vast tract of country west of the Mississippi in order to provide for the future needs of the then young republic. The truth, however, compels us to recognize the fact that neither the American people of that day-who were few in number compared with the extent of their existing territory, and who already possessed ample lands beyond their power of cultivation-nor their statesmen in their farthest vision foresaw the amazing development destined to come before the end of the century. Jefferson's plans, not anticipating, but following the demands of the "west," only sought to provide for an existing emergency, and to acquire in perpetuity a right which had been once conceded to the United States by Spain - the right of a free depot and transfer of their products. That was the attitude of our government when Monroe sailed for France. Its eyes were directed to the south, not to the west.

The real scene of the story of the Louisiana Purchase is on the other side of the Atlantic. It is laid in Paris, where the proposal of the greater transaction had its origin in 
the breast of the powerful master of the French republic.

The First Consul, under the pressure of European hostilities, was contemplating an act of transcendant importance to our country. $\mathrm{He}$ had secretly held all of Louisiana at his disposal since October, 1800, although our ministers in France and Spain had been kept in ignorance of it. So late as the spring of 1803, Talleyrand deceptively denied the French title in a conversation with Livingston. But now a renewal of the war with England was threatened. The British navy was dominant on the sea, and an English expedition might at any time seize New Orleans, and France would lose the colony without compensation. His thoughts were already bent on a sale to the United States by which he hoped not only to satisfy our large pecuniary claims which we were pressing against his government, but to obtain besides a large surplus to reinforce his treasury for the coming war. He directed Marbois, his minister of finance, to offer the entire Province of Louisiana to the United States, and to demand in compensation one hundred million francs, together with the assumption by our government of the American claims against France for her outrages on our commerce. He said to his advisers with some passion in his voice that England coveted that colony and could easily make a descent there; but she should not have it. For France to retain it would be folly. He would cede the whole to the United States. This was the situation when Monroe arrived in Paris; for this startling proposal had been already communicated to Livingston, who could hardly credit the sincerity of the offer.

The prospect of this vast and complete acquisition which would for the second time eliminate French control from the American continent and settle the question of commercial depots forever, aroused intense interest in both the American envoys, but especially in the mind of Livingston. Communication with the United States by occasional sailing vessels was slow and uncertain. In that day neither telegraph nor steamship was available. A royal message to the English 
parliament had just announced the British preparation for renewing the war with France. If anything was to be done with Louisiana it must be done quickly. Our envoys could not wait for new instructions. With true American courage they resolved to take the responsibility upon themselves, and without authority win a new empire for the young republic. They protested against the extravagance of the sum demanded as beyond the resources of the American government, and succeeded in reducing the amount of purchase money to sixty millions of francs, and in limiting the assumption of American claims to twenty millions of francs. They then concluded the three treaties with all haste. They were signed on the 30th of April, 1803. The war cloud hanging over the English channel burst eighteen days after the signature. When the names of the plenipotentiaries were appended to this unexpected convention of purchase, Livingston enthusiastically grasped the hands of Marbois and Monroe, saying: "We have lived long, but this is the noblest work of our lives!' The praise for this magnificent accomplishment is more due to Robert R. Livingston than to any other American; and some city or county in every state formed out of this imperial purchase should bear his name in commemoration of his courageous statesmanship.

ACQUISITION DENOUNCED, BUT JUSTIFIED BY HISTORY.

The purchase money was indeed a great sum to pay out of the limited treasury and unestablished national credit of the United States of that day. Bitter opposition was aroused in this country against the ratification of the treaty. The acquisition was derided as of little worth, wholly unnecessary, and tending to weaken the old states. It was declared to be an excessive extension of territory which would lead to a disruption of the Union. The prophets of woe were as effusive then over the enlargement of our territory as they have been ever since over the successive expansions which have illuminated the pages of our national history. The evil predictions of 1803 are now buried deep in the drift of time. The very 
names of the false prophets are in oblivion, while the many happy millions who inhabit the twelve states and two territories now lying within the limits of the Louisiana Purchase have forever repudiated the old forecasts of evil. Instead of diminishing, the older states have greatly increased their population and prosperity with the settlement and development of the new. The newer states have also forged new bands for the strengthening of the Union. The bravest blood offered to the nation in its historic struggle for liberty and Union, and in its struggle for the maintenance of the national power and glory abroad, has flowed from the veins of men who were nourished on this new soil of the republic. Patriotism, courage, energy, flow forth with every heart-beat of the child of the new west. He has subdued the savagery which dominated the prairies and plains and mountains of the Louisiana of 1803. $\mathrm{He}$ has covered the rolling prairies and plains with grazing herds and smiling harvests, with schoolhouses for happy children and churches for an untrammeled religion. He has uncovered the hidden caves of rich metals in the great mountains of northwestern Louisiana, and has enriched his whole country with the elements of a new and unbounded prosperity. Whenever and wherever his nation's flag has been thrown to the breeze at home or abroad, in Mexico or Alaska, in Cuba or other islands of the sea, under the great wall of China, or in the mountain fastnesses of Luzon, wherever deeds of loyalty, of courage and of daring are required, there in the front rank of volunteers is heard the quick response of the loyal sons of the west. New strength has been acquired for the constitution and the Union, new hope for the country's prosperity is created with every new breath born in the expanded territory of our republic.

It may be further confidently affirmed that our national character has not deteriorated during the century in which we have followed the providential law of our national growth and development. We have seen in what manner this law was introduced and historically established. I call it providential 
because neither our statesmen nor our people proposed it or foresaw it. The national representatives of that day, including Jefferson himself, when informed of the convention signed by our envoys in Paris, doubted its constitutionality, or were astounded by the resulting increase of the public debt. They adopted it chiefly because of the evident perils to existing national interests which would follow its rejection.

THE STORY OF LOUISIANA DRAMATIC-HER FATE PROVIDENTIAL.

The whole story of Louisiana involves much that is dramatic and unexpected. De Soto merely crossed its central river and died without discovering its mouth or exploring its course, although his decimated followers later escaped through its outlet without any act of possession. Consequently Spain acquired no title to the river valley. Then came France, whose explorers from Canada made discoveries from the sources downward, and later found its outlet by sea and took possession upward. Her right to the country was therefore beyond dispute. Had the French retained possession of all their discoveries they would have imprisoned the future American republic between the Alleghanies and the Atlantic. But this was not the Divine purpose. England conquered Canada, and eastern Louisiana followed the fate of her sister province and became British colonial territory. As a consequence, the latter fell to the United States upon the recognition of their independence. So it happened that our people at the end of the revolutionary war found themselves in possession as far as the Mississippi, but there were barred from all further western progress so long as Spain held all the vast territory west of the river.

Had the boundary remained there for a hundred years, no human mind can conceive the change it would have made in the destiny of this nation. Without the wheat fields and corn fields and the cattle ranges of the prairies and plains of the Trans-Mississippi, without the lead and iron ores of Missouri, without the vast deposits of gold and silver and copper 
of the western mountain ranges, with no roads across the continent, with no harbors on the Pacific coast, without possession of the mouth of the Mississippi, without any port on the Gulf of Mexico, above all without the incentive to our individual activities and national development that these sources of wealth have afforded - no human intellect, no poet's imagination, can portray what would have been our fate or our condition today as influenced or controlled by the nations which might have possessed them. What wars might have ensued, what liberties might have perished, what miseries might have befallen!

But at the providential moment there appeared upon the European horizon a new and dominant personal force in the French republic which overawed Spain, and her king yielded to the demand of "Citizen Bonaparte," and restored Louisiana to France. This again threatened to be a more serious obstacle to our growth than was the power of Spain, for the military force of France was far greater. But two years later France finds it impracticable to retain Louisiana owing to her naval inferiority to England, and Bonaparte suddenly, without the knowledge of the government at Washington, conveys the title finally and forever to the United States. Even then Spain, alarmed at the absolute and final disposal of the country by France, protests our title because of an alleged condition attached to her retrocession to France. This condition was officially notified to the United States that Louisiana should never be conveyed by France to a third power. But Bonaparte imperatively insisted that delivery should be made to him under the cession of 1800 , which was done; and he immediately thereafter, on the 20th of December, 1803, transferred the possession of New Orleans to the United States. The Lewis and Clark expedition, conceived without expectation of our possible ownership, was thus enabled to explore the territory of Louisiana under our own flag. But we had at that time no acknowledged title to the country westward of the mountains to the Pacific coast. Spain, 
Great Britain, and Russia were on that coast before us. Equally in the order of providence, and just in time, the New England Captain Gray, under the American flag, was the first to enter the mouth of the great river of Oregon in 1792, which under international law gave to the United States the claim of discovery, and this claim was strongly reinforced by the succeeding exploration of Lewis and Clark. With this inchoate right on the Pacific coast the United States was able by later treaties to permanently establish our title on that shore, with well defined limits between the Spanish territory on the south and the British on the north.

THE PRIZE CONTESTED IN TWO WARS.

Our acquisition of Louisiana had been accomplished by the pacific methods of diplomacy. But the permanent possession of it by our Union was only to be preserved at the cost of great treasure and by the sacrifice of many lives. In less than twelve years from the date of the cession by France, while we were at war with Great Britain that power despatched an expedition to seize the mouth of the river, accompanied by an army for the capture of New Orleans. The men of the lower valley rushed to arms, met the invading enemy, and drove him back to the sea. The dramatic feature of Louisiana's history again appears in the fact that this battle was fought after the signature of peace, of which the tidings had nut yet reached the combatants. This battle, however, brilliant as it was on the part of the American volunteers, hardly rises to the dignity of a tragedy in comparison with the prolonged struggle which followed a half century later.

This incomparable valley, dowered with inexhaustible wealth, and like Helen of Troy possessed of the fatal gift of beauty, was destined to become the scene of the greatest conflict known in the history of the American continent-a conflict, please God! never to be renewed. On this 30th day of May, devoted by the affection of the American people to the memory of the heroes of the war for the Union, we canVoL. V.,-13. 
not forget the splendid services of the men who by their indomitable courage again saved the lower Mississippi to the United States together with all the original Louisiana on both banks below the mouth of the Ohio.

In our great civil struggle Louisiana and its river once more became the mighty stake played for in the terrible game of war. Again the question was presented of the northern right of access to the sea by way of the river, and of the control of the delta at its mouth. Vaster commercial interests than ever before were in suspense. Once more, also, a Bonaparte appeared on the borders of the scene gazing eagerly from Mexico upon the still coveted territory which had been ceded by his great predecessor. The brave and stalwart men of the valley, in former contests united, were now unhappily divided into hostile camps. As never before it was now a battle of giants, equally brave, equally resolved. The issue hung long in a balance, the scales of which were filled with blood. But the great-hearted men of the upper valley clothed themselves in the panoply of the Union, drew in a mighty inspiration from the sentiment of expanding human liberty, and fought four long years to regain the untrammelled freedom of the great river from all its sources to the sea. The bones of our heroic dead who perished in that fearful struggle lie scattered along all the river shores from the Missouri to the gulf. But they did not die in vain. We owe it to their unfaltering courage that since the end of these years of battle, and we trust for all time to come, every rivulet that falls eastward down the rugged ranges of the Rocky mountains, or that ripples southward from the far springs of the Canadian frontier, or that leaps westward down the slopes of the Alleghanies, dances along all its winding way through the old Louisiana to the southern sea under the folds of the star-spangled banner and to the music of the Union. All hail to the memory of these heroes dead; and all hail to their comrades who live to salute the dawn of this day dedicated to the memory of their deeds! 
EXPANSION A VITAL LAW OF THE REPUBLIC.

Such is the outline of the story of Louisiana, first tossed to and fro between France and Spain, and then imperiously tossed by the French executive to the envoys of the United States. Later it was twice subjected to the wager of battle. Its acquisition is especially significant in our history, as it was the first enlargement of that original territory which our fathers thought sufficient for our children until the "hundredth generation." Based upon Louisiana, the republic continued its expansion across the middle of the continent from the great ocean of the sunrise to the greater ocean of the sunset. Our republic did not dream yet of the wider expansion which was still enfolded in the shadow of her future destiny. She awaited the reappearance of the index finger of providence.

But important events of our history have taught us one great truth of our heredity as a people. Expansion is in the blood of our race. Organized liberty demands a broadening sphere of action. A single generation may pause to organize and utilize what a previous one has acquired. But a succeeding generation will reassert the inherent impulse of the race so long as barbarism remains on the earth unsubdued. Under christian auspices it is the providential law which from age to age opens up new regions to the influences of a higher civilization, and uplifts the inferior races by contact with the superior. The right to enforce civilized usages among mankind is higher and holier than the right to maintain barbaric practices and inhuman laws. The better has an inherent moral right to expand over the worse. The justice and humanity of the motive will forever consecrate the onward movement with a divine sanetion. Peace and order, liberty and prosperity, education and morality, have hitherto followed the advancing flag of the American republic. Wild beasts have given place to peaceful herds and flocks. The wandering wigwam has been replaced by the settled home. The ground of the war-dance is occupied by the school house, and the pole hung with scalp-locks by the steeple of the 
church. The vast desert spaces are now laughing with harvests, and the various tribes of the white men are c'welling there in unity. Who can doubt that such expansion is in accord with the purposes of the Almighty in the regeneration of the world?

In this spirit and with such purpose the expansion of the republic has more widely advanced in later years. The beneficent changes to be wrought in the alien races may require a full generation or more for their accomplishment. The work of the school house is slow. The work of the church is dilatory. But we have the glorious assurance of the past that we are now doing the will of the great ruler of nations while we follow our providential law. Since the middle of the last century we have been led on step by step beyond the ocean boundary of our continent, following the sun in his western course, until scores of islands of the southern and central Pacific have come peacefully under the dominion of the United States. The Alaskan Islands carried the jurisdiction of the republic within the longitudes of northern Asia. By an unforeseen emergency of the Spanish war, declared for another and a humane purpose, we came into the unexpected possession of the Philippine Islands, on the south of the Asiatic continent. Like Louisiana, their purchase and annexation were unforeseen by the statesmen and people of our country; and, like Louisiana, they will in the process of civilization reveal unexpected resources for the blessing of mankind and for the advancement and security of the republic.

A CENTURY OF GLORY.

We look back with amazement and with gratitude upon this century of our history. The first year of the nineteenth century found our youthful nation barred on the west by our great mediterranean river, and shut off from the sea on the south, with the barriers guarded by two formidable military powers of Europe. Our incipient commerce was wantonly destroyed on the high seas, the common prey of warring European navies, without fear of reprisals or punishment. 
Even the paltry powers of the Barbary coast levied tribute on our commercial vessels and held captured American citizens in slavery. Our political parties at home were more hostile to each other than to the foreigners who insulted our flag. The republic was neither respected nor envied, neither courted nor feared, by any power of Europe, or Asia, or Africa.

But now, in the first year of the twentieth century, all this is changed. Our matured nation is in possession of the whole northern shore of the gulf, including all the peninsula of Florida, with her jurisdiction extended across the continent to the shore of the Pacific, and leaping thence to the farthest coast of Alaska. Our flag floats over a thousand islands of the western ocean. It was the first to be welcomed in the harbors of Japan, of Korea, and of China as the emblem of international peace and justice. The fame of our navy is wafted around the world by every wind that blows, and the flag that covers its guns assures protection to our commerce on every sea and in the harbors of every continent. The republic is respected and honored as one of the great physical and moral powers of the world. At home a common patriotism unites our political parties as never before. It has been exhibited during this month when all political parties in various parts of this great country have been assembling to greet and acclaim a president, who is himself the soul of patriotism and national honor.

It is a marvelous expansion, a marvelous transformation, a miracle of the nations!

Thanks be to the Almighty Power which has so directed our destiny that in this first summer of the new century, and in the third generation of the explorers of the west, the sun never sets upon the territory of the republic. That brilliant orb which today gilds the summit of this monument will shed his bright beams in every hour of his daily circuit around the globe upon some state or territory, some plain or mountain or island shore, over which floats the beneficent flag of 
our expanded republic, carrying in its folds the assurance of peace and liberty, order and security, education and civilization to all the inhabitants. May this great memorial stand for ages to come to remind our children of the manly virtues of their race, which in the nineteenth century made the republic so glorious in the annals of history.

\section{THE RUSH TO IOWA.}

We yesterday saw Jas. Chisnell, Esq., of Summit county, just returned from the Decorah land office, Iowa, where with thousands of others he had been waiting for weeks for the purpose of entering some government land. The rush was so great that the crowd would fill up the passage way to the office at night and stand on their feet till morning, in order to be first in. Some froze their toes and some their feet, waiting for the office to open. This was called the "stair system." The outsiders finally organized some three hundred strong and drew numbers from a hat for their turns, pledging to stand by one another, as against those who persisted in the stair system. Upon the drawing, printed numbers were issued to the drawers, from 1 to 300 , signed by the chairman of the committee, which certificates of numbers soon became currency, by bearing a premium of from $\$ 5$ to $\$ 50$ for those entitled to draw first. The officer could wait upon but four or five customers per day, which would throw the high numbers some months ahead. So Mr. Chisnell and others come home and wait a month or so when they expect to return in time to take their chances according to their numbers.-Cleveland (O.) Plaindealer, Feb. 20, 1856. 
Copyright of Annals of Iowa is the property of State of Iowa, by \& through the State Historical Society of Iowa and its content may not be copied or emailed to multiple sites or posted to a listserv without the copyright holder's express written permission. However, users may print, download, or email articles for individual use. 